\title{
ANALISIS KUALITAS PELAYANAN AKADEMIK DAN ADMINISTRASI TERHADAP KEPUASAN MAHASISWA DAN ALUMNI PADA MASA PERALIHAN SEKOLAH TINGGI AGAMA ISLAM NEGERI (STAIN) MENJADI INSTITUT AGAMA ISLAM NEGERI (IAIN) BATUSANGKAR
}

\section{Sri Adella Fitri}

Fakultas Ekonomi dan Bisnis Islam, IAIN Batusangkar.

J I. Sudiman No.137 Kuburajo, Limakaum, Batusangkar, Sumatera Barat, Indonesia adellaciza@yahoo.com

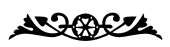

\begin{abstract}
So far, various performance measurements have been done by IAIN Batusangkar, for example, through Annual Working Report, which illustrates the achievement of targets that have been planned. The development of one of the performance measurements that focuses on measuring the performance of non-financial IAIN is from the consumer view-point namely the students and alumni. It is expected to be able to provide comprehensive improvement on the satisfaction of students and alumni on the quality of service that has been given IAIN, good quality of administration services, quality of service teaching and learning process and all academic processes that have been experienced. This research is a field research i.e., descriptive quantitative, that is explaining satisfaction and loyalty of the students and alumni to the quality of academic and administrative services in the transition period from State College for Islamic Studies (STAIN) to become State Institute for Islamic Studies (IAIN) Batusangkar. Based on the calculation of the students' and the alumni's satisfaction, it was found that the obtained total satisfaction was 67.96\%, and 76.84\%. It means that the consumers' satisfaction (in this case students' and alumni's) on the performance of IAIN Batusangkar has not satisfactory.
\end{abstract}

Keywords: service quality, students' satisfaction, and alumni's satisfaction

\section{PENDAHULUAN}

Salah satu penentu keberhasilan suatu perusahaan yaitu dengan memenuhi kebutuhan pelanggannya. Dengan memenuhi kebutuhan pelanggan, perusahaan akan dapat mencapai keuntungan yang diharapkan. Kebutuhan pelanggan akan tercapai melalui kepuasan pelanggan atas apa yang diperolehnya. Banyak sekali faktor yang merujuk kepada kepuasan pelanggan, seperti kualitas produk yang dihasilkan, harga produk yang ditawarkan, pelayanan saat penjualan dan purna jual, dan banyak faktor lainnya.

Berbeda dengan perusahaan, lembaga pendidikan tinggi merupakan organisasi publik yang tidak berorientasi kepada laba. Tetapi lebih menitikberatkan kepada kepuasan layanan yang diberikan kepada para stakeholdernya. Stakeholder yang dimaksud adalah mahasiswa, dosen dan 
karyawan, alumni, dan para pengguna lulusan. Jika perusahaan swasta memenuhi kebutuhan pelanggan dalam rangka pencapaian kepuasan pelanggan, beorientasi kepada laba yang maksimal, sedangkan lembaga pendidikan memenuhi kebutuhan pelanggannya untuk perbaikan dan peningkatan kualitas di masa yang akan datang. Mengapa? Karena lembaga pendidikan tinggi tidak hanya berfokus pada hasil akhir dari sebuah proses, tetapi mencakup pada proses yang dijalankan sehingga mencapai hasil yang diharapkan. Untuk memperoleh hasil yang diharapkan yaitu lulusan yang terserap diberbagai sektor, tentu melalui sebuah proses yang tidak hanya berjalan apa adanya. Proses yang dijalankan harus memiliki kualitas yang telah ditetapkan. Salah satunya kualitas pelayanan terhadap mahasiswa. Apakah mahasiswa telah memperoleh pelayanan yang maksimal. Pelayanan yang dimaksud adalah memenuhi segala kebutuhan mahasiswa sebagai salah satu bagian dari lembaga pendidikan tinggi yaitu pelayanan administrasi, perbaikan proses belajar mengajar, perbaikan sarana dan prasarana dan lain-lain.

Pentingnya lembaga pendidikan tinggi memperhatikan hal tersebut karena pendidikan tidak hanya berfokus pada hasil akhir proses pendidikan, tetapi melalui akuntabilitas yang baik melalui jaminan kualitas, pengendalian kualitas, perbaikan kualitas (Badan Akreditasi Nasional Perguruan Tinggi, 2011).
Di samping itu, dengan disahkannya Undang-undang Republik Indonesia No. 9 Tahun 2009 tentang Badan Hukum Pendidikan, menjadikan lembaga pendidikan agar dikelola seperti sebuah industri perusahaan, hal ini menjadikan perlunya optimalisasi dari pengelolaan lembaga pendidikan agar mampu bersaing baik dengan sesama perguruan tinggi negeri maupun dengan perguruan tinggi swasta. Intinya adalah bagaimana sebuah perguruan tinggi mampu meningkatkan dan mempertahankan kualitasnya, baik kualitas lulusan, kualitas biaya, kualitas pelayanan, dan kualitas SDM yang dimiliki.

Peralihan status Sekolah Tinggi Agama Islam Negeri (STAIN) Batusangkar menjadi Institut Agama Islam Negeri (IAIN) melalui Peraturan Presiden (PERPRES) No. 147 Tahun 2015 tentang perubahan STAIN Batusangkar menjadi IAIN Batusangkar, merupakan salah satu perguruan tinggi agama yang berada dibawah naungan Kementerian Agama yang berusaha melakukan peningkatan status untuk kemajuan perguruan tinggi dimasa yang akan datang. Peningkatan status ini juga diiringi dengan berbagai peningkatan dari berbagai aspek sebagai penunjang kegiatan operasional IAIN ke depan. Tidak hanya peningkatan dibidang akademik tetapi juga dibidang non akademik. Disamping itu, pada masa-masa peralihan ini IAIN tetap menjaga kualitas layanan dalam berbagai aspek, baik pelayanan kepada dosen, mahasiswa dan alumni. Berdasarkan data statistik mahasiswa dan karyawan IAIN 
Batusangkar tahun 2016, dengan jumlah mahasiswa yang semakin meningkat yaitu 4009 orang jika dibandingkan dengan jumlah dosen dan karyawan yang ada yaitu 144 orang dosen tetap dan 23 orang dosen kontrak, dan 75 orang dosen luar biasa, 55 karyawan tetap dan 73 karyawan kontrak, apakah jumlah mahasiswa dengan jumlah dosen dan karyawan sudah sebanding atau mencukupi untuk terlaksananya kegiatan akademik yang berkualitas, sehingga menghasilkan output yang sesuai dengan visi dan misi IAIN secara umum.

Untuk menilai pelaksanaan berbagai kegiatan, sejauh ini berbagai pengukuran kinerja telah dilakukan oleh IAIN Batusangkar misalnya melalui Laporan Kerja Tahunan, yang menggambarkan pencapaian target-target yang telah direncanakan. Tapi hal itu hanya mencerminkan pencapaian kegiatan dengan realisasi biaya yang telah dianggarkan. Melihat kondisi saat ini dan sejalan dengan UU No.9 Tahun 2009 tentang Badan Hukum Pendidikan bahwa ukuran kinerja tidak hanya diukur melalui pencapaian target-target yang telah ditetapkan dan kesesuaiannya dengan anggaran yang telah disahkan, tetapi pengukuran kinerja juga harus dilihat dari semua sisi, yaitu keuangan dan non keuangan, karena IAIN merupakan Perguruan Tinggi yang tujuan akhirnya bukan untuk memaksimalkan laba atau merealisasikan anggaran, yang menjadi prioritas adalah output akhir yang berkualitas yaitu sarjana yang kompeten yang siap bersaing.
Berdasarkan fenomena yang terjadi, peneliti mengembangkan salah satu pengukuran kinerja yang menfokuskan untuk mengukur kinerja IAIN yang bersifat non keuangan, yaitu dari sisi konsumennya yaitu mahasiswa dan alumni, yang diharapkan dapat memberikan perbaikan menyeluruh mengenai kepuasan mahasiswa dan alumni terhadap kualitas pelayanan yang telah diberikan IAIN, baik kualitas pelayanan administrasi, kualitas pelayanan proses belajar mengajar dan semua proses akademik yang dilalui.

Berdasarkan latar belakang yang dipaparkan diatas, peneliti tertarik untuk meneliti dengan tema Analisis Kualitas Pelayanan Akademik dan Administrasi Terhadap Kepuasan Mahasiswa dan Alumni pada Masa Peralihan Sekolah Tinggi Agama Islam Negeri (STAIN) Batusangkar menjadi Institut Agama Islam Negeri (IAIN) Batusangkar.

\section{KAJIAN TEORI}

\section{Pengertian Kinerja dan Pengukuran Kinerja}

Kinerja adalah keberhasilan personil, tim, atau unit organisasi dalam mewujudkan sasaran strategik yang telah ditetapkan sebelumnya dengan dengan rendahnya retensi pegawai. perilaku yang diharapkan (Mulyadi, 2007: 337). Sedangkan menurut Mangkunegara (2000: 67) mengemukakan kinerja adalah hasil kerja secara kualitas dan kuantitas yang dicapai seorang pegawai 
dalam melaksanakan tugasnya sesuai dengan tanggung jawab yang diberikan kepadanya. Selain itu, kinerja merupakan kombinasi dari kemampuan, usaha dan kesempatan yang dapat dinilai dari hasil kerjanya (Sulistiyani, 2003: 223)

Jadi, dapat disimpulkan bahwa kinerja adalah kemampuan, usaha dan kesempatan personil, tim, atau unit organisasi dalam melaksanakan tugasnya untuk mewujudkan sasaran strategik yang telah ditetapkan.

\section{Manfaat Pengukuran Kinerja}

Ada beberapa hal yang membuat pengukuran kinerja itu penting. Di antaranya menurut Lynch dan Cross (1993), manfaat sistem pengukuran kinerja yang baik adalah sebagai berikut:

1. Menelusuri kinerja terhadap harapan pelanggan sehingga akan membawa perusahaan lebih dekat dengan pelanggannya dan membuat seluruh orang dalam organisasi terlibat dalam upaya memberi kepuasan kepada pelanggan.

2. Memotivasi para pegawai untuk melakukan pelayanan sebagai bagian dari matarantai pelanggan dan pemasok internal.

3. Mengidentifikasi berbagai pemborosan sekaligus mendorong upaya-upaya pengurangan terhadap pemborosan tersebut.

4. Membuat suatu tujuan strategis yang biasanya masih kabur, menjadi lebih nyata sehingga mempercepat proses pembelajaran organisasi.

5. Membangun komitmen untuk melakukan suatu perubahan dengan melakukan evaluasi atas perilaku yang diharapkan tersebut.

\section{Organisasi Sektor Publik}

Sektor publik menurut Muindro (2008: 6) merupakan suatu organisasi yang tidak semata-mata mencari keuntungan. Sehingga dari pengertian itu dapat kita pahami bahwa sifat dari organisasi sektor publik itu sendiri bukanlah untuk mencari laba.

Ada beberapa faktor lingkungan yang dapat mempengaruhi sektor publik, yaitu: (Muindro, 2008: 6-7)

a. Faktor ekonomi, yang mempengaruhi sektor publik dari faktor ekonomi diantaranya adalah pertumbuhan ekonomi, tingkat inflasi, pendapatan perkapita, struktur produksi, tenaga kerja, arus modal, cadangan devisa, teknologi, dll

b. Faktor politik, yang berpengaruh terhadap sektor publik dari faktor politik diantaranya adalah hubungan masyarakat negara, legitimasi pemerintah, ideologi negara, kelembagaan, dll

c. Faktor kultural, di mana yang mempengaruhi sektor publik dari faktor kultural adalah agama, suku, ras, budaya, bahasa, sejarah, sosiologi masyarakat, dan pendidikan. 
Husaini (2008: 459) menjelaskan tujuan dari penilaian kinerja sebagai berikut:

a. Lebih menjamin objektivitas dalam pembinaan calon pegawai dan pegawai berdasarkan sistem karir dan sistem prestasi kerja.

b. Memperoleh bahan-bahan pertimbangan objektif dalm pembinaan calon pegawai dan PNS dalam membuat kebijakan seperti promosi, hukuman, pemecatan, dll.

c. Memberi masukan untuk mengatasi masalah yang ada, misalnya kurang terampil atau perlu keterampilan baru (untuk menentukan jenis pelatihan dan pengembangan karir calon pegawai dan pegawai)

d. Mengukur validitas metode penilaian kinerja yang digunakan

e. Mendiagnosa masalah-masalah organisasi

f. Umpan balik bagi calon pegawai dan pegawai serta pimpinan

\section{Pengertian Kepuasan}

Kotler dan Keller (2003) mendefinisikan kepuasan konsumen sebagai perasaan konsumen, baik itu berupa kesenangan atau kekecewaan yang timbul dari membandingkan penampilan sebuah produk dihubungkan dengan harapan konsumen atas produk tersebut.

Kepuasan konsumen merupakan keseluruhan sikap yang ditunjukkan konsumen atas barang atau jasa setelah mereka memperoleh dan menggunakannya. Ini merupakan penelitian evaluatif pascapemilihan yang disebabkan oleh seleksi pembelian khusus dan pengalaman menggunakan barang atau jasa tersebut (Mowen dan Minor, 2002). Kepuasan konsumen adalah persepsi individu terhadap performansi suatu produk atau jasa dikaitkan dengan harapan konsumen tersebut (Sciffman dan Kanuk, 2004).

\section{Faktor-faktor yang Mempengaruhi Kepuasan Pelanggan}

Kepuasan pelanggan ditentukan oleh persepsi pelanggan atas performance produk atau jasa dalam memenuhi harapan pelanggan. Pelanggan merasa puas apabila harapannya terpenuhi atau akan sangat puas jika harapan pelanggan terpenuhi. Namun, kita juga harus mengetahui apa faktor-faktor yang mendorong terpenuhinya harapan pelanggan tersebut. Menurut Handi Irawan (2008: 37-39) ada lima driver (Penggerak) utama kepuasan pelanggan, yaitu:
a. Kualitas produk.
b. Harga.
c. Sevice quality.
d. Emotional factor (faktor emosi)

\section{Tipe-Tipe Kepuasan Konsumen}

Stauss \& Neuhaus (dalam Tjiptono \& Gregorius, 2005) membedakan tiga tipe kepuasan dan dua tipe ketidakpuasan, yakni:
a. Demanding customer satisfaction.
b. Stable customer satisfaction. 

c. Resigned customer satisfaction.
d. Stable customer dissatisfaction.
e. Demanding dissatisfaction.

\section{Nilai Pelanggan}

Nilai bagi pelanggan (customer value) merupakan perbedaan antara nilai yang dinikmati pelanggan karena memiliki serta menggunakan suatu produk dan biaya untuk memiliki produk tersebut, (Kotler, 2001: 188). Sebagaimana disampaikan Rangkuti (2006: 26) bahwa, yang dibutuhkan oleh pelanggan adalah pelayanan serta manfaat dari produk tersebut.

Kriteria nilai bagi pelanggan (customer value) dapat digambarkan sebagai berikut:

Nilai bagi pelanggan $=\frac{\text { Kualitas }}{\text { Biaya }} \times \frac{\text { Layanan }}{\text { Waktu }}$

Menurut Sweeney dan Soutar (2001: 203-220), dimensi nilai terdiri atas empat aspek utama sebagai berikut:

a. Emotional value.

b. Social value.

c. Quality/performance value.

d. Pricelvalue for money. Senoaji (2008: 28) menyarankan kepuasan adalah persepsi pelanggan dari value yang diterima dalam suatu transaksi atau hubungan. (Tjiptono, 2004: 34) menyatakan konsep kepuasan pelanggan, kualitas jasa/layanan, dan nilai pelanggan (costumer value) berkaitan erat.

\section{Pengukuran Kepuasan Konsumen}

Menurut Kotler \& Amstrong (2003), ada empat metode yang bisa digunakan untuk mengukur kepuasan konsumen, yaitu:

a. Sistem Keluhan dan Saran

Setiap perusahaan yang berorientasi pada konsumen (customer oriented) akan memberikan kesempatan yang sebesar-besarnya bagi konsumen untuk menyampaikan pendapat, saran dan keluhan konsumen.

b. Survei Kepuasan Konsumen

Penelitian mengenai kepuasan konsumen banyak dilakukan dengan menggunakan metode survei, baik melalui pos, telepon maupun wawancara pribadi.

c. Ghost Shopping

Metode ini dilaksanakan dengan cara memperkerjakan beberapa orang (ghost shopper) untuk bersikap sebagai konsumen di perusahaan pesaing.

d. Analisa Konsumen yang Hilang Metode ini dilaksanakan dengan cara perusahaan menghubungi para konsumennya yang telah berhenti membeli atau yang telah beralih pemasok dan perusahaan menanyakan penyebab konsumen berhenti membeli atau beralih pemasok. 


\section{Dimensi Kualitas Pelayanan dalam Perspektif Islam}

\section{a. Dimensi kualitas pelayanan dalam perspektif Islam}

Dalam pandangan Islam yang dijadikan tolak ukur untuk menilai kualitas pelayanan yaitu ketentuan syariah. Islam mensyariatkan kepada manusia agar selalu terikat kepada hukum syara' dalam menjalankan setiap aktivitas ataupun memecahkan setiap permasalahan.

Ada lima dimensi kualitas pelayanan yang mempengaruhi kepuasan pelanggan: 1

\section{1) Tangible (bukti langsung)}

Tangible meliputi fasilitas fisik, perlengkapan karyawan dan sarana komunikasi. (Rangkuti: 2002: 30). Maksudnya adalah suatu bentuk penampilan fisik, peralatan yang lengkap. Salah satu catatan penting bagi pelaku pelayanan publik, bahwa dalam menjalankan operasionalnya haruslah memperhatikan sisi penampilan fisik para pengelola atau petugasnya dalam hal penampilan yang sesuai tuntunan syariat. Hal ini sesuai dengan firman Allah dalam Q.S al-A'ra,f: 26:

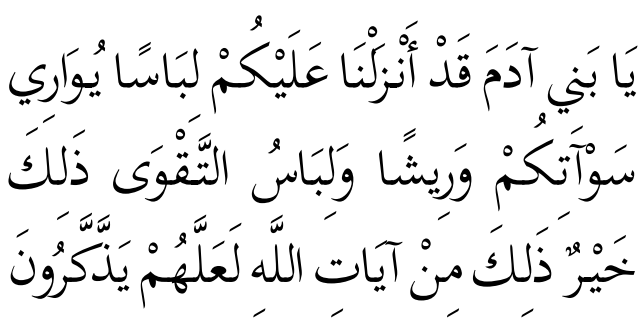

Hai anak Adam, Sesungguhnya Kami telah menurunkan kepadamu pakaian untuk menutup auratmu dan pakaian indah untuk perhiasan. dan pakaian takwa Itulah yang paling baik. yang demikian itu adalah sebahagian dari tanda-tanda kekuasaan Allah, Mudahmudahan mereka selalu ingat.

Dari sini dapat dipahami dua fungsi dari sekian banyak fungsi pakaian. Pertama, sebagai penutup bagian-bagian tubuh yang dinilai oleh agama atau dinilai oleh seseorang atau masyarakat sebagi buruk bila dilihat, dan yang kedua, adalah sebagai hiasan yang menambah keindahan pemakainya.

2) Reliability (kehandalan)

Reliability yaitu kemampuan untuk melakukan pelayanan sesuai yang dijanjikan dengan segera, akurat dan memuaskan, (Shihab, 2008: 58). Artinya, apa yang diberikan dengan sopan dan ramah. Sebagai seorang muslim, telah ada contoh teladan yang tentunya bisa dijadikan pedoman dalam menjalankan aktivitas. Allah SWT berfirman dalam Q.S Al-Ahzab: 21:

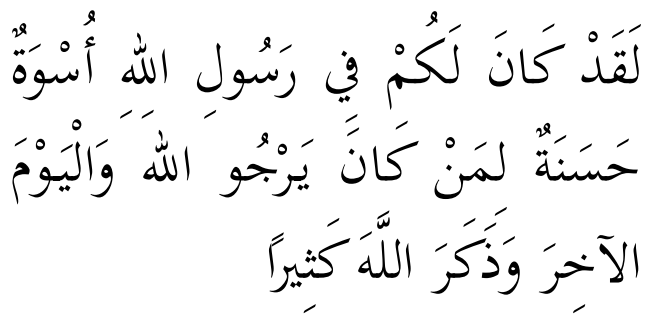

Sesungguhnya telah ada pada (diri) Rasulullah itu suri teladan yang baik bagimu (yaitu) bagi orang yang mengharap (rahmat) Allah dan (kedatangan) hari kiamat dan Dia banyak menyebut Allah. 
Ayat ini memberikan gambaran kepada manusia untuk selalu berakhlak baik seperti yang dicontohkan Rasulullah SAW.

\section{3) Responsiveness (ketanggapan)}

Responsiveness Adalah kemampuan untuk menolong pelanggan dari ketersediaan untuk melayani pelanggan dengan baik. (Rangkuti, 2008: 30). Artinya suatu respon atau kesigapan dalam membantu dan memberikan pelayanan yang cepat dan tanggap. Dalam Islam kita harus selalu menepati komitmen seiring dengan promosi yang dilakukan. Berkaitan dengan hal ini Allah SWT berfirman dalam Q.S. Al-Maidah: 1

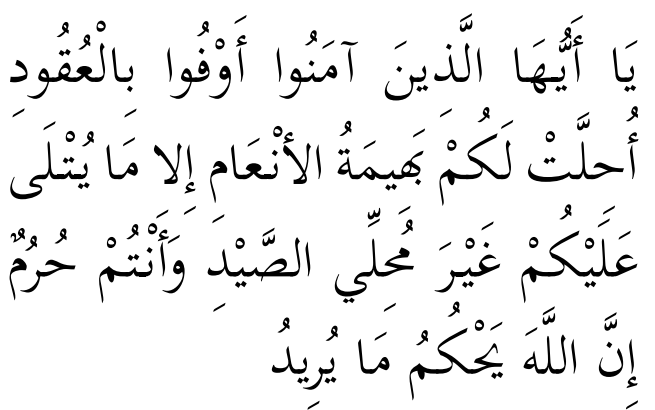

Hai orang-orang yang beriman, penubilah aqad-aqad itu. Dihalalkan bagimu binatang ternak, kecuali yang akan dibacakan kepadamu. (yang demikian itu) dengan tidak menghalalkan berburu ketika kamu sedang mengerjakan haji. Sesungguhnya Allah menetapkan hukumhukum menurut yang dikehendaki-Nya.

Ayat ini menjelaskan bahwa segala macam 'aqad, janji dan kontrak, dan sebagainya diakui oleh Islam, dan wajib diteguhi dan dipenuhi, apabila dimungkiri ia telah melepaskan diri dari ciri-ciri orang beriman. (Hamka, 1983: 106).
Disamping itu Allah SWT juga berfirman dalam Q.S. Al- Insyirah, 7 yang artinya:

Maka apabila kamu telah selesai (dari sesuatu urusan), kerjakanlah dengan sungguh-sungguh (urusan) yang lain.

Sebagai ahli tafsir menafsirkan, apabila kamu (Muhammad) telah selesai berdakwah maka beribadatlah kepada Allah SWT, apabila kamu telah selesai mengerjakan urusan dunia maka kerjakanlah urusn akhirat. (Hamka, 1983: 106). Ayat ini menunjukan bahwa Allah SWT menyuruh manusia agar profesional dalam bekerja dan peringatan Allah SWT kepada manusia agar tidak menunda-nunda pekerjaan.

\section{4) Assurance (jaminan)}

Assurance adalah pengetahuan, kesopanan petugas serta sifatnya yang dapat dipercaya sehingga pelanggan terbebas dari resiko. (Rangkuti, 2008: 30). Artinya kemampuan untuk menimbulkan kepercayaan dan menimbulkan rasa aman serta pertanggung jawaban atas kesalahan yang dilakukan. Sesuai dengan firman Allah SWT dalam QS Al-Azhab: 72:

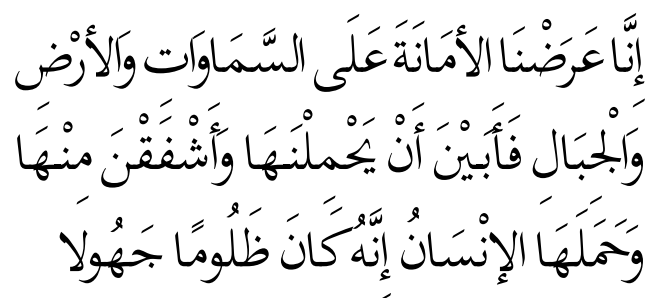

Sesungguhnya Kami telah mengemukakan amanat kepada langit, bumi dan gununggunung, Maka semuanya enggan untuk memikul amanat itu dan mereka khawatir 
akan mengkhianatinya, dan dipikullah amanat itu oleh manusia. Sesungguhnya manusia itu Amat zalim dan Amat bodoh.

Ada beberapa pendapat mengenai makna amanah dalam ayat ini. Al-Qurthubi menyatakan, amanah bersifat umum mencakup seluruh tugas-tugas keagamaan. Ini adalah pendapat jumhur. Asy-Syaukani menukil pedapat al-Wahidi, bahwa amanah disini menurut pendapat seluruh ahli tafsir adalah ketaatan dan kewajiban-kewajiban yang penunaiannya dikaitkan dengan pahala dan pengabaiannya dikaitkan dengan siksa.

\section{5) Empathy (empati)}

Empati adalah rasa peduli untuk memberikan perhatian secara individual kepada pelanggan, memahami kebutuhan pelanggan serta kemudahan untuk dihubungi. (Rangkuti: 30). Artinya kemampuan pegawai dalam memberikan perhatian yang bersifat individual atau pribadi. Allah SWT, berfirman dalam QS. An-Nahl: 90

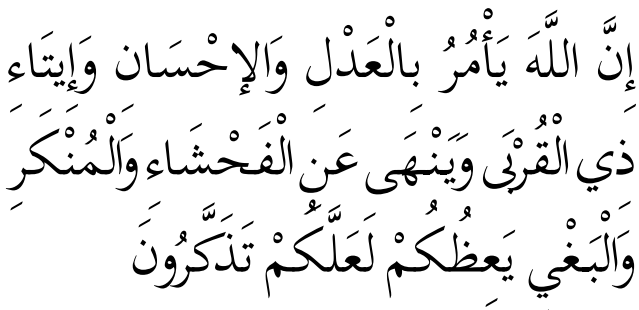

Sesungguhnya Allah menyuruh (kamu) Berlaku adil dan berbuat kebajikan, memberi kepada kaum kerabat, dan Allah melarang dari perbuatan keji, kemungkaran dan permusuhan. Dia memberi pengajaran kepadamu agar kamu dapat mengambil pelajaran.

\section{METODOLOGI PENELITIAN}

\section{Jenis Penelitian}

Jenis penelitian yang penulis gunakan dalam penelitian ini adalah penelitian lapangan (field research) yang bersifat deskriptif kuantitatif, yaitu menjelaskan kepuasan dan loyaliatas mahasiswa dan alumni terhadap kualitas pelayanan akademik dan administrasi pada peralihan dari (Sekolah Tinggi Agama Islam Negeri) STAIN menjadi (Institut Agama Islam Negeri) IAIN Batusangkar.

\section{Jenis Data dan Sumber Data}

Jenis data yang dikumpulkan berupa data kuantitatif dan kualitatif serta sumber data terdiri dari data primer dan sekunder. Data primer dikumpulkan dari jawaban responden berupa:

1. Kuesioner terhadap kepuasan mahasiswa.

2. Kuesioner terhadap kepuasan alumni

Data sekunder yaitu data-data yang sudah tersedia pada instansi berupa:

a. Data pegawai/karyawan dan dosen

b. Data mahasiswa dan kemahasiswaan

c. Prosentase tingkat perputaran karyawan, tingkat produktifitas karyawan, pelatihan karyawan, kemampuan sistem informasi, motivasi.

d. Sejarah singkat dan struktur organisasi. 


\section{Teknik Pengumpulan Data}

Untuk mengumpulkan data digunakan beberapa teknik yaitu:

1. Dokumentasi, merupakan teknik pengumpulan informasi dengan cara mengumpulkan dokumen-dokumen yang berhubungan dengan penelitian seperti laporan keuangan. (Ibnu, 2000: 61).Dalam penelitian ini peneliti menggunakan teknik dokumentasi untuk mengambil data internal IAIN Batusangkar seperti sejarah, profil, dan struktur organisasi dan data-data kegaitan penunjang yang dilaksanakan seperti data-data pelatihan untuk karyawan, dosen dll.

2. Kuesioner merupakan teknik pengumpulan data yang dilakukan dengan cara memberi seperangkat pertanyaan atau pertanyaan tertulis kepada responden untuk dijawabnya. (Achmad, 2010: 199). Dalam penelitian ini daftar pertanyaan atau kuisioner akan peneliti gunakan untuk memperoleh informasi tentang tanggapan mahasiswa dan alumni IAIN Batusangkar mengenai pelayanan, sistem akademik, sarana dan prasarana serta PBM pada IAIN Batusangkar.

Pertanyaan disusun berdasarkan sepuluh respon, lima di antaranya respon untuk menyatakan pelayanan (performance) yaitu SP (sangat puas), P (puas), CP (cukup puas), KP (kurang puas), TP (tidak puas), sedangkan lima respon untuk tingkat kepuasan yaitu SP (sangat puas), P (puas), CP (cukup puas), KP (kurang puasa), TP (tidak puas).

\section{Populasi dan Sampel}

1. Populasi

Populasi dari penelitian yang penulis lakukan adalah seluruh mahasiswa dan alumni IAIN Batusangkar. Berdasarkan data statistik pegawai dan mahasiswa IAIN Batusangkar tahun 2016, peneliti memperoleh data populasi pegawai dan dosen sebanyak 199 orang yang tetap dan 171 orang tidak tetap, sedangkan jumlah mahasiswa sebanyak 4.009 orang dan jumlah alumni sebanyak 6.629 orang.

2. Sampel

Sampel dari penelitian ini adalah beberapa orang pada lembaga dan instansi pengguna lulusan IAIN Batusangkar, dan untuk mahasiswa dan alumni digunakan teknik Random Sampling. Yaitunya suatu metode pemilihan sampel, di mana setiap populasi memiliki peluang yang sama untuk dipilih menjadi anggota sampel. Sampel yang digunakan menggunakan rumus (Rakhmat,1993: 53):

$$
\mathrm{n} \geq \frac{\mathrm{N}}{1+\mathrm{N} e^{2}}
$$

\footnotetext{
Keterangan:

$\mathrm{n} \quad=$ Jumlah sampel

$\mathrm{N}$ = Jumlah populasi

$\mathrm{e} \quad=$ Nilai presisi yang diharapkan tidak menyimpang lebih dari $10 \%$
} 
Jumlah sampel untuk mahasiswa yang digunakan adalah 97 orang dari populasi yang ada. Sedangkan jumlah sampel untuk alumni yang digunakan adalah 100 orang dari populasi yang ada.

\section{Pengujian Sistem Informasi}

\section{Uji Validitas}

Uji validitas dilakukan melalui perbandingan antara nilai $r$ hitung terhadap $r$ tabel. Bila $r$ hitung $>\mathrm{r}$ tabel, maka pertanyaan dalam kuesioner dinyatakan valid.

Rusmus yang dipakai dalam uji validitas ini adalah sebagai berikut (Purwano, 2010: 127):

$$
r x y=\frac{\mathrm{N}\left(\sum \mathrm{xy}\right)-\left(\sum \mathrm{x}\right)\left(\sum \mathrm{y}\right)}{\left.\sqrt{[\mathrm{N}} \sum \mathrm{x}^{2}-\left(\sum \mathrm{x}\right)^{2}\right]\left[\mathrm{N} \sum \mathrm{y}^{2}-\left(\sum \mathrm{y}\right)^{2}\right]}
$$

\section{Keterangan:}

rxy = Koefisien korelasi product moment antara X dan $\mathrm{Y}$

$\mathrm{X}=$ Skor Pernyataan setiap nomor

$\mathrm{Y}=$ Skor total

$\mathrm{N}=$ Jumlah responden

\section{Uji Reliabilitas}

Dalam SPSS ada fasilitas yang dapat di gunakan untuk mengukur reliabilitas yaitu melalui uji statistik cronbach alpha dan variabel di katakan reliabel jika nilai cronbach alpha $>0.60$. Rumusnya adalah sebagai berikut:

$$
r 11=\left(\frac{k}{k-1}\right)\left(\frac{1-\sum \partial^{2} b}{\partial^{2} t}\right)
$$

\section{Keterangan:}

$\mathrm{r} 11=$ realibilitas Instrument

$\mathrm{k} \quad=$ Banyaknya butir pernyataan

$\Sigma \partial 2 \mathrm{~b}=$ Jumlah varian butir

$\partial 2 \mathrm{t}=$ Varian total

\section{Analisis Data}

Untuk menjawab masalah mengenai tingkat kepuasan mahasiswa dan alumni terhadap kinerja manajemen IAIN Batusangkar serta kepuasan pengguna lulusan dengan menggunakan Customer Satisfaction Index. Menurut Stratford dalam Aminah, dkk (2008), metode pengukuran CSI meliputi tahapan, yaitu:

a. Menghitung importance weighting factors (faktor kepentingan terbobot), yaitu mengubah nilai rataan tingkat kepentingan menjadi angka presentase dari total nilai rataan tingkat kepentingan untuk seluruh atribut yang diuji, sehingga didapatkan total importance weighting factors $100 \%$.

b. Menghitung weighted score (skor terbobot) yaitu nilai perkalian antar nilai rataan tingkat kepuasan masing-masing atribut dengan importance weighting factors masing-masing atribut.

c. Menghitung weighted total (total terbobot), yaitu menjumlahkan weighted score dari semua atribut mutu jasa.

d. Menghitung satisfaction index (indeks kepuasan), yaitu weighted total dibagi skala maksimal yang digunakan (skala maksimal 5), kemudian dikalikan 100\%.

Tingkat kepuasan responden secara menyeluruh dapat dilihat dari kriteria tingkat kepuasan konsumen. Adapun kriterianya berdasarkan Aditiawarman, dengan kriteria: 
$0,00-0,34=$ Tidak puas

$0,35-0,50=$ Kurang puas

$0,51-0,65=$ Cukup puas

$0,66-0,80=$ Puas

$0,81-1,00=$ Sangat Puas

\section{ANALISIS DAN PEMBAHASAN}

\section{Data Kualifikasi Dosen dan Karyawan IAIN Batusangkar}

Sumber daya manusia merupakan salah satu unsur utama dalam pelaksanaan tri dharma perguruan tinggi. Sumberdaya manusia pada saat ini berjumlah 370 yang terdiri dari 199 orang pegawai tetap/PNS dan 171 Pegawai tidak tetap, seperti tabel berikut:

\section{Berdasarkan Jenis Kepegawaian}

\begin{tabular}{|l|l|l|}
\hline Pegawai Tetap & Peg. Tidak Tetap & Jumlah \\
\hline 199 & 171 & 370 \\
\hline
\end{tabular}

Pegawai tetap berjumlah 199 orang terdiri dari 144 dosen dan 55 orang tenaga administrasi, sedangkan pegawai tidak tetap 171 orang terdiri dari 98 orang dosen serta 73 orang tenaga administrasi seperti tabel berikut:

\section{a) Berdasarkan Jenis Fungsi}

\begin{tabular}{|l|l|l|l|}
\hline Keterangan & Dosen & Tenaga Adm & Jumlah \\
\hline Peggawai Tetap & 144 & 55 & 199 \\
\hline Pegawai Kontrak & 23 & 73 & 96 \\
\hline Dosen Luar Biasa & 75 & - & 75 \\
\hline
\end{tabular}

Tenaga pengajar saat ini 242 orang yang terdiri dari dosen tetap 144 orang serta dosen kontrak berjumlah 23 orang, dan dosen luar biasa 75 orang, dengan jumlah mahasiswa 4009 orang maka ratio antara mahasiswa dengan dosen adalah $1: 16$.

Tenaga pengajar saat ini memiliki latar belakang jabatan dan tingkat pendidikan seperti pada tabel dibawah ini

\section{b) Rekapitulasi Dosen Berdasarkan} Jabatan

\begin{tabular}{|l|l|l|l|l|l|l|}
\hline Keterangan & $\begin{array}{l}\text { Guru } \\
\text { Besar }\end{array}$ & $\begin{array}{l}\text { Lektor } \\
\text { Kepala }\end{array}$ & Lektor & $\begin{array}{l}\text { Asisten } \\
\text { Ahli }\end{array}$ & Cados & Jumlah \\
\hline Tetap & 1 & 27 & 72 & 24 & 20 & 144 \\
\hline
\end{tabular}

2. Rekapitulasi Dosen Berdasarkan Pendidikan

\begin{tabular}{|c|c|c|c|c|}
\hline Keterangan & Doktor ( S3) & Magister (S2) & Sarjana (S1) & Jumlah \\
\hline Tetap & 29 & 111 & 4 & 144 \\
\hline
\end{tabular}

Tenaga administrasi saat ini berjumlah 128 orang yang terdiri dari pegawai tetap 55 orang dan pegawai tidak tetap 73 orang, dengan latar belakang tingkat pendidikan serta pangkat dan golongan seperti pada tabel dibawah ini

\section{Rekapitulasi Tenaga Administrasi} Berdasarkan Pendidikan

\begin{tabular}{|l|l|l|l|l|l|l|l|}
\hline Ket. & $\begin{array}{l}\text { Magister } \\
(\text { S2 })\end{array}$ & $\begin{array}{l}\text { Sarjana } \\
(\text { S1 })\end{array}$ & $\begin{array}{l}\text { Diploma } \\
(\text { D III })\end{array}$ & SLA & SMP & SD & Jumlah \\
\hline Tetap & 16 & 27 & 5 & 6 & 0 & 1 & 55 \\
\hline
\end{tabular}

\section{PEMBAHASAN}

Pelanggan yang dimaksudkan disini adalah mahasiswa yang status akademiknya aktif kuliah dan alumni. Sehingga untuk mengukur kepuasan pelanggan akan dibagi menjadi 2 yaitu: mengukur kepuasan mahasiswa terhadap kinerja dosen, sistem manajemen, sarana dan prasarana serta sistem informasi dan mengukur kepuasan alumni atas semua proses yang yang telah 
dilalui selama menjadi mahasiswa di IAIN Batusangkar.

Pengukuran kepuasan pelanggan adalah mutlak diperlukan untuk dua hal. Pertama, agar perusahaan tidak membuang uang percuma. Tanpa pengukuran, perusahaan tidak akan mampu menentukan prioritas perbaikan kualitas produk atau pelayanan yang diharapkan oleh pelanggannya. Kedua, agar perusahaan dapat menggalang komitmen dari semua lapisan karyawannya untuk terlibat dalam proses peningkatan kepuasan pelanggan. (Irawan: 2003).

Pemantauan dan pengukuran terhadap kepuasan pelanggan telah menjadi hal yang sangat esensial bagi setiap perusahaan atau organisasi, termasuk dalam dunia pendidikan dalam hal ini yang menjadi pelanggannya adalah mahasiswa. Dikarenakan langkah tersebut dapat memberikan umpan balik dan masukan kepada keperluan pengembangan dan implementasi strategi peningkatan kepuasan pelanggan. Pada prinsipnya kepuasan pelanggan itu dapat diukur dengan berbagai macam metode dan tekhnik. Salah satunya melalui Survei kepuasan pelanggan.

Kepuasan pelanggan dalam hal ini mahasiswa dan alumni dianalisis dengan menggunakan formula sebagai berikut:

Kepuasan Pelanggan $=\frac{\text { Total Skor }}{\text { Jumlah Total Skor Pertanyaan x Jumlah Mahasiswa }} \times \quad$ 100\%

Kepuasan Mahasiswa terhadap kinerja IAIN Batusangkar

Dari pengolahan data yang dilakukan di dapatkan hasil berikut:

$$
\begin{aligned}
\text { Kepuasan Pelanggan } & =\frac{10.874}{16.000} \times 100 \% \\
& =0,6796 \times 100 \% \\
& =67,96 \%
\end{aligned}
$$

Dengan menggunakan kriteria Aditiawarman, perhitungan kepuasan mahasiswa di atas dapat terlihat dari beberapa aspek yang dijabarkan dalam angket yaitu bahwa total kepuasan yang diperoleh sebesar $67,96 \%$, ini berarti bahwa konsumen dalam hal ini mahasiswa merasa puas terhadap kinerja IAIN Batusangkar. Artinya, walaupun kondisi peralihan status STAIN menjadi IAIN, ternyata kondisi ini sedikit berpengaruh terhadap kualitas layanan terhadap mahasiswa. IAIN tetap memberikan pelayanan kepada mahasiswa pada saat yang bersamaan juga melakukan berbagai pembenahan. Hal ini menunjukkan tingkat kepuasan mahasiswa belum pada kondisi yang maksimal. Itu artinya IAIN Batusangkar tetap terus melakukan berbagai perbaikan dan peningkatan, sehingga kepuasan mahasiswa terhadap berbagai fasilitas akademik dan non akademik semakin baik dan meningkat. Karena hal ini merupakan salah satu indikator penilaian kinerja IAIN Batusangkar dalam mencapai berbagai prestasi dimasa depan.

\section{Kepuasan Alumni terhadap kinerja IAIN Batusangkar}

Dari pengolahan data yang dilakukan di dapatkan hasil berikut: 


$$
\begin{aligned}
\text { Kepuasan Pelanggan } & =\frac{4.895}{6.370} \text { X } 100 \% \\
& =0,7684 \times 100 \% \\
& =76,84 \%
\end{aligned}
$$

Dengan menggunakan kriteria Aditiawarman, perhitungan kepuasan alumni di atas dapat terlihat bahwa nilai kepuasan yang diperoleh sebesar 76,84\%, ini berarti bahwa konsumen dalam hal ini alumni merasa puas terhadap kinerja IAIN Batusangkar. IAIN tetap memberikan pelayanan kepada alumni pada saat yang bersamaan juga melakukan berbagai pembenahan. Kepuasan alumni ini juga didukung karena kebanggaan alumni atas pencapaian peningkatan status STAIN menjadi IAIN, sehingga alumni bangga dengan keberhasilan yang telah diperoleh oleh IAIN. Walaupun demikian kepuasan yang dirasakan belum pada tataran yang maksimal, itu artinya IAIN Batusangkar tetap terus melakukan berbagai perbaikan dan peningkatan, sehingga kepuasan alumni terhadap berbagai fasilitas akademik dan non akademik yang telah mereka rasakan semakin baik dan meningkat. Sehingga tingginya kepuasan alumni akan menjadi salah satu cara promosi secara tidak langsung kepada berbagai pihak eksternal.

\section{PENUTUP}

\section{Kesimpulan}

Kepuasan pelanggan dibagi menjadi 2 yaitu: mengukur kepuasan mahasiswa terhadap kinerja dosen, sistem manajemen, sarana dan prasarana serta sistem informasi dan mengukur kepuasan alumni atas semua proses yang yang telah dilalui selama menjadi mahasiswa di IAIN Batusangkar. Kepuasan yang diukur dilakukan pada saat terjadinya peralihan status dari Sekolah Tinggi Agama Islam Negeri (STAIN) menjadi Institut Agama Islam Negeri (IAIN) Batusangkar.

Perhitungan kepuasan mahasiswa berdasarkan survey yang dilakukan terlihat dari beberapa aspek yang dijabarkan dalam angket yaitu bahwa total kepuasan yang diperoleh sebesar 67,96\%, ini berarti bahwa konsumen dalam hal ini kepuasan mahasiswa belum maksimal terhadap kinerja IAIN Batusangkar.

Sedangkan kepuasan alumni berdasarkan survey yang dilakukan terlihat bahwa nilai kepuasan yang diperoleh sebesar 76,84\%, ini berarti bahwa konsumen dalam hal ini alumni merasa puas terhadap kinerja IAIN Batusangkar.

\section{KEPUSTAKAAN ACUAN}

Achmad Sani Supriyanto. 2010. Metodologi Riset Manajemen Sumberdaya Manusia. UIN-Maliki Press: Malang

Badan Akreditasi Nasional Perguruan Tinggi. 2011

Departemen Agama RI, Al-Quran dan Terjemahannya, (Bandung: Diponegoro, 2000).

Fandy Tciptono, Strategi Pemasaran, (Yogyakarta: Andi Offset, 2004). 
Fredly Rangkuti, Measuring Customer Satisfaction: Teknik Mengukur dan Strategi Meningkatkan Kepuasan Pelanggan, (Jakarta: PT. Gramedia Pustaka Utama, 2002).

Hamka, Tafsir Al-Azhar: Juz V-VI, (Jakarta: Pustaka Panjimas, 1983).

Husaini Usman. 2008. Manajemen: teori, praktik, dan riset pendidikan. Bumi Aksara: Jakarta

Handi Irawan, Handi Irawan, Sepuluh Prinsip kepuasan Pelanggan, (Jakarta; Alex Media Komputindo, 2008).

Handi Irawan, Indonesian Customer Satisfaction: Membedah Strategi kepuasan Pelanggan Merk Pemenang ICSA, (Jakarta: PT. Gramedia, 2003).

Ibnu Subiyanto. 2000. Metodologi Penelitian Manajemen dan Akuntansi. UPP AMP YKPN: Yogyakarta

Indra Bastian. 2006. Akuntansi Sektor Publik. Erlangga: Yogyakarta

Mardiasmo. 2002. Akuntansi Sektor Publik. CV Andi Offset: Yogyakarta

M. Quraishy Shihab, Tafsir Al-Misbah: Pesan, Kesan dan Keserasian Al-Quran (Tangerang: Lentera Hati, 2008).

Moenir, Manajemen Pelayanan Umum di Indonesia, (Jakarta: Bumi Askara, 2008).
Muindro Renowijoyo. 2008. Akuntansi Sektor Publik: Organisasi Non Laba. Mitra Wacana Media: Jakarta

Mulyadi, Sistem Pengendalian Manajemen. (Jakarta: Salemba Empat, 2007)

Philip Kotler, Dasar-dasar Manajemen: Terjemahan Buku Philip Kotler dan Gary Amstrong, Principles of Marketing, (Jakarta: Prenhallindo, 1997), Edisi Indonesia.

Philip Kotler, Manajemen Pemasaran (Jakarta: Prenhallindo, 2003), Edisi Indonesia.

Purwanto, Instrumen Penelitian Sosial dan Pendidikan, (Yogyakarta: Pustaka Pelajar, 2010).

Rambat Lupiyadi dan A. Hamdani, Manajemen Pemasaran Jasa, (Jakarta: Salemba Empat, 2006), Edisi Ke- 2.

Sekaran, Uma. 2006. Metodologi Penelitian Bisnis Edisi 1. Salemba Empat. Jakarta

Sekaran, Uma. 2006. Metodologi Penelitian Bisnis Edisi 2. Salemba Empat. Jakarta

IAIN Batusangkar, 2016, Data Statistik Pegawai IAIN Batusangkar

IAIN Batusangkar, 2016, Data Mahasiswa dan Alumni IAIN Batusangkar

Undang-undang Republik Indonesia No.9 Tahun 2009 tentangBadan Hukum Pendidikan 